\title{
Scorpion sting during pregnancy: A case report accompanied by literature
}

\section{Gebelikte akrep sokmasının literatür eşliğinde dĕgerlendirilmesi}

\section{Zeynep Kamalak*, Nermin Koşuş}

Obstetrics Clinic (Z. Kamalak, MD), Nenehatun State Hospital, TR-25070, Erzurum, Department of Gynecology and Obstetrics (Assist. Prof. N. Koşuş, MD), Turgut Özal University School of Medicine, TR-06010 Ankara

\begin{abstract}
Envenomation is an unusual event in developed countries. Rural population who lives in arid climate is incur this danger. Scorpion sting is one of the envenomation. It is a major public health problem in many underdeveloped tropical countries. In Turkey, epidemiological studies have shown that most scorpion stings affect females. The highest incidence of scorpion stings was recorded for the warmest months of the year since scorpions become more active in the warm season. Diagnosis is obvious from the history. Also pain, erythema, induration, and wheal may be present at the sting point. In pregnancy envenoming is more dangerous but scorpion envenoming is less studied during gestation; however, it may induce various biological disturbances in maternal organism and on their fetuses. In this article the aim is bring on a subject for discussion on a case report.
\end{abstract}

Keywords: Scorpion envenomation, pregnancy

\section{Özet}

Envenomizasyon yani yılan veya akrep gibi zehirli sürüngen ve haşerelerle sokularak zehirlenme kurak iklimin hakim olduğu kırsal bölge halkı için ciddi bir risktir. Türkiye'de yapılan epidemiyolojik çalışmalar bu durumdan özellikle dişilerin etkilendiğine işaret etmektedir. Tanı ise anamneze bağlı olup ağrı, eritem, endurasyon ve belki haşerenin sokma noktasının görülmesine bağlıdır. Gebelikte envenomizasyon ise çok daha riskli olmasına rağmen üzerinde oldukça az çalışılmış bir konudur oysa ki hem maternal ve hem de fetal riskler söz konusudur. Biz bu yazımızda bir vakamızı literatür eşliğinde tartışmak istedik.

Anahtar sözcükler: Akrep sokması, gebelik

Geliş tarihi/Received: December 18, 2012; Kabul tarihi/Accepted: December 02, 2013

\section{*Corresponding author:}

Dr. Zeynep Kamalak, Kadın Doğum Kliniği, Nenehatun Devlet Hastanesi, TR-25070 Erzurum. E: mail: drzkmlk@gmail.com

\section{Introduction}

Turkey commonly presents scorpions and human envenomation cases due to its geographical location, climate and socioeconomic structure. The highest incidence of scorpion stings was recorded for the warmest months of the year since scorpions become more active in the warm season [1-3]. Envenomation statistics are not available for insect bite exposures because most cases are not reported and do not require hospital care. One of the envenomation type is scorpion sting. Mortality and morbidity of insect bites is associated with the reaction form either anaphylactic reaction or complications resulting from infection. Scorpion stings in pregnancy has been scarcely searched in the literature. Some animal studies demonstrated some harmful effects of scorpion toxin to fetus and the 
mother. In an animal study Ben Nasr et al. [4] elucidated some biological effects of such poisoning in late pregnant rats. Their results suggest that scorpion envenomation may induce some disturbances and threatens both mother's and fetus' well-being. The neurotoxins found in scorpion venom that are harmful to humans affect mainly sodium channels in excitable cells [5].

\section{Case report}

A 24 years old G3P2 at 31 weeks of gestation pregnant women was admitted to the Afşin Public Hospital in July 2010 after being stung by scorpion two times on her left foot within 2 hours. She arrived to the hospital approximately 45 minutes after having been stung. The victim was complained of fear. During examination of the affected area it was not possible to identify precisely where the scorpion had penetrated the skin, only a minimal erythema was seen. Her medical and obstetric history included two spontaneous labors in home. The patient vital signs and her physical examination were normal. By the ultrasound examination the measurements of the baby was compatible with 31 weeks, amniotic fluid index was normal, and there was not any apparent plasental problem. No contractions were recorded and fetal monitoring was normal. The patient was hospitalizied for observation. After a day of observation she was discharged from the hospital. All urgency conditions were told her to come back to hospital if they occur. Routine ultrasound and non-stress test controls were done and seven weeks later at 38 weeks gestation she was admitted to Afşin Public Hospital because of rupture of membranes and uterine contractions. Her vaginal examination was showed $70 \%$ effacement and $5 \mathrm{~cm}$ dilatation with clear amniotic fluid discharge. She delivered a male $3200 \mathrm{~g}$ newborn vaginally without any problem.

\section{Discussion}

Scorpion sting is especially common in Southeast Anatolia Region of Turkey. The reaction to sting may be local or systemic. It can develop in a minute or up to several hours after the initial insult. Toxic reactions of scorpion venoms depend on several factors. Signs and symptoms depend on various factors including genus, species, age, weight, feeding state and structure of the scorpion, as well as the amount of venom injected, the number of stings, the stung site, the patient's susceptibility, the time spent between the sting and the first medical aid, and the climate of the region [6]. Toxins may cause local pain, swelling, skin inflammation which can be caused by direct toxic effects and/or hypersensitivity to the venom. If the allergic reaction is severe enough, it cause swelling beneath the skin called angioedema, bronchospasm and laryngeal swelling and life-threatening anaphylactic shock is the result. If the symptoms of the envenomation is severe the treatment is antivenom administration within the shortest possible time. The severity of the condition can be divided into four phase.

1. Grade I-Local pain or paresthesia at the sting site (83\%).

2. Grade II-Pain or paresthesia that has traveled from the sting site $(9.1 \%)$.

3. Grade III-Either cranial nerve or somatic neuromuscular dysfunction (4.7\%).

4. Grade IV-Both cranial nerve and somatic neuromuscular dysfunction (3\%).

At present there are no established guidelines for treatment, concerning an exotic species. According to the phase treatment can be supportive or antivenom application. The best result occurs when antivenom is administered as early as possible especially at Grade III and IV. There are many arguments about whether specific or polyvalent antivenom is the best approach [7, 8]. Because the clinical manifestations and severity of the symptoms vary among patients, individualized management of scorpion stings is the best approach. Additionally scorpion envenomation in pregnant victims has been scarcely studied [9].

In literature there is a few anecdotal observations of yellow scorpion stings resulting in early abortions in pregnant women [10]. There is a case report in literature that the patient have fetal death following a yellow scorpion sting [11]. Venoms may act uterine muscle 
directly or may act indirectly by causing the release of or potentiating the effect of bradykinins on uterine muscle [12].

Treatment generally consists of moving the patient away from the scorpion and stabilizing the patient's airway and vital signs, followed by administration of antivenom and institution of symptomatic and local treatment. The best results are obtained by administration of antivenin as early as possible. Whether these signs represent a reaction to the treatment and, if so, the underlying mechanisms and their toxicological impact remain to be examined in future studies.

\section{References}

1. Adiguzel S. In vivo and in vitro effects of scorpion venoms in Turkey: A minireview. J Venom Anim Toxins incl Trop Dis 2010; 16: 198-211.

2. Adiguzel S, Ozkan O, Inceoglu B. Epidemiological and clinical characteristics of scorpionism in children in Sanliurfa, Turkey. Toxicon 2007; 49: 875-80.

3. Ozkan O, Karaer Z. The scorpions in Turkey. Turk Bull Hyg Exp Biol 2003; 60: 55-62.

4. Ben Nasr H, Serria H, Chaker S, Riadh B, Zouheir S, Kamel J, Tarek R, Khaled Z.Some biological effects of scorpion envenomation in late pregnant rats. Exp Toxicol Pathol 2009; 61: 573-80.

5. Dutto M, Dutto L, Scaglione N, Bertero M. Euscorpius (Scorpiones, Euscorpiidae): Three cases of stings in northwestern Italy. J Venom Anim Toxins incl Trop Dis 2010; 16: 45-9.

6. Dittrich K, Ahmed R, Ahmed QA. Cardiac arrest following scorpion envenomation. Ann Saudi Med 2002; 22: 87-90.

7. Chippaux JP, Goyffon M. Epidemiology of scorpionism: A global appraisal. Acta Tropica 2008; 107: 71-9.

8. Ozkan O, Adıgüzel S, Inceoglu B, Lango J, Ertek M, Hammock BD. Evaluation of the neutralizing capacity of Androctonus crassicauda (Olivier, 1807) antivenom against Leiurus quinquestriatus (Ebrenberg, 1928) venom (Scorpiones: Buthidae). J Venom Toxins incl Trop Dis 2008; 14: 481-96.

9. Langley RL A review of venomous animal bites and stings in pregnant patients. Wilderness Environ Med 2004; 15: 207-15.

10. Osman $\mathrm{OH}$, Ismail M, El-Asmar MF, Ibrahim SA EVect on the rat uterus on the venom from the scorpion Leiurus quinquestriatus. Toxicon 1972; 10: 363-6.

11. Lilach Leibenson, M. Leibenson, T.Silberstein Antepartum fetal death following a yellow scorpion sting.Arch Gynecol Obstet 2010; 281: 247-9.

12. Gomes A, De P, Dasgupta SC. Occurrence of a unique protein toxin from the Indian King Cobra (Ophiophagus hannah) venom. Toxicon 2001; 39: 363-70. 